\title{
Moisture and Salinity Stress Induced Changes in Biochemical Constituents and Water Relations of Different Grape Rootstock Cultivars
}

\author{
Satisha Jogaiah, Sahadeo D. Ramteke, Jagdev Sharma, and Ajay Kumar Upadhyay \\ National Research Centre for Grapes, P. B. No. 3, Manjri Farm, Solapur Road, Pune, Maharashtra 412 307, India \\ Correspondence should be addressed to Satisha Jogaiah; satilata@gmail.com
}

Received 25 June 2013; Accepted 28 October 2013; Published 20 January 2014

Academic Editor: Ravindra N. Chibbar

Copyright (c) 2014 Satisha Jogaiah et al. This is an open access article distributed under the Creative Commons Attribution License, which permits unrestricted use, distribution, and reproduction in any medium, provided the original work is properly cited.

\begin{abstract}
Ten grape rootstocks were subjected to moisture and salinity stress in two separate experiments. The influence of these stresses on gas exchange, water relation, and biochemical parameters was monitored at various stages of stress cycle. Both stresses indicated significant changes in the physiological and biochemical parameters studied. Some biochemical constituents increased by several folds in few rootstock cultivars which also recorded increased osmotic potential suggesting their role in osmotic adjustment. Some of the rootstock cultivars such as 110R, 1103P, 99R, Dogridge, and B2/56 recorded increased phenolic compounds under stressed conditions. The same rootstock also recorded increased water use efficiency. The increased accumulation of phenolic compounds in these cultivars may indicate the possible role of phenolic compounds as antioxidants for scavenging the reactive oxygen species generated during abiotic stresses thus maintaining normal physiological and biochemical process in leaves of resistant cultivars.
\end{abstract}

\section{Introduction}

Water scarcity and soli salinity are the major hurdles for grape cultivation as the majority of the area under grape cultivation is concentrated in the semiarid tropical climate of India. The combined effect of these two abiotic stresses in these regions contributed to a decline in the productivity of own-rooted vineyards. Hence, interest in grape rootstocks has intensified, owing to the problems of salinity and drought. Over dependence on a single rootstock Dogridge necessitated the growers to use other rootstocks as some rootstocks cannot perform well under all soil and climatic conditions. Rootstocks are known to influence physiology and biochemical process of the grafted scion varieties as evidenced by several studies. Hence, it is necessary to study the mechanisms by which rootstocks respond to drought and salinity stresses. Rootstocks have been reported to alter the water status and gas exchange parameters of scion varieties in both potted [1] and field conditions [2]. The most important mechanism is that rootstocks genotypes have a major influence on root density [3] although the distribution of grapevine roots is significantly dependent on both soil characteristics and vine spacing.
Salt stress in higher plants is regulated by a number of physiological and biochemical processes. High level of salt causes an imbalance of cellular ions resulting in both ion toxicity and osmotic stress causing a production of active $\mathrm{O}_{2}$ species (AOS) as superoxide, hydrogen peroxides, and hydroxyl radicals [4]. To reduce AOS induced damage, plants have evolved intricate antioxidative systems, involving antioxidant enzymes, as well as low molecular weight secondary metabolites such as ascorbate, glutathione, tocopherols, carotenoids, and phenolic compounds [5]. Biological and antioxidant properties of phenolic compounds among other metabolites have extensively been studied [6]. Protein and secondary metabolites of leaves from a variety of plants have been examined and were found to be promising as markers, such as dehydrin, and ASR proteins (abscisic acid ripening induced proteins), under moisture stress conditions.

Different plant species and genotypes within a species respond differently to salt and water stress. So the objective of the present study was to determine the changes in physiological and biochemical components in the leaves of different grape rootstocks subjected to moisture and salinity stress during different stages of stress cycle. 


\section{Materials and Method}

2.1. Location and Plant Materials. The experiment was conducted in two separate sets each one for moisture stress and salinity stress at the research plots of National Research Centre for Grapes, Pune. Ten rootstock varieties belonging to different Vitis species were used in the study. The details of rootstocks used with their species or parentage are as follows:

\author{
Dogridge: Vitis champinii, \\ Salt Creek (synonym Ramsey): Vitis champinii, \\ St. George: Vitis rupestris, \\ 1613C: solonis $\times$ othello, \\ 110R: Vitis berlandieri $\times$ Vitis rupestris, \\ 99R: Vitis berlandieri $\times$ Vitis rupestris, \\ 1103P: Vitis berlandieri $\times$ Vitis rupestris, \\ B2-56: Vitis berlandieri $\times$ Vitis rupestris, \\ Vitis longii, \\ Teleki 5A: Vitis berlandieri $\times$ Vitis riparia .
}

Hardwood cuttings of the selected rootstock varieties were taken from rootstock mother blocks and planted for rooting in polythene bags filled with soil, sand, and farm yard manure. When the cuttings attained about 3 months age they were transplanted to plastic pots containing soil, sand, and farm yard manure in the proportion of $2: 1: 1$. The plants were irrigated, fertilized, and protected with regular management practices for six months to develop sufficient root and shoot systems.

2.2. Soil Moisture Stress Studies. Six-month rootstock vines were selected for evaluating rootstocks for moisture stress tolerance and all the rootstocks were divided into two groups each having 10 pots. One group received full irrigation regularly while the other group received 50\% irrigation calculated as per the field capacity. The moisture stress cycle was imposed for 21 days. At regular intervals observation on gas exchange parameters (photosynthetic rate, transpiration rate), water relation parameters (relative water content, water potential, and osmotic potential), and biochemical parameters (total phenols, reducing sugars, proteins, and proline) were recorded.

2.3. Salinity Stress Studies. In this study selected rootstocks were grouped into two categories of 10 potted plants each, in which one group received salinity treatment of $2 \mathrm{dS} \mathrm{m}^{-1}$ and the other received $4 \mathrm{dS} \mathrm{m}^{-1}$. The salinity stress was created by calculating the quantity of sodium chloride required to reach 2 and $4 \mathrm{dS} \mathrm{m}^{-1}$ of soil salinity. The desired quantity of salt was dissolved in water and irrigated on alternate days in the stress cycle of 25 days. All the gas exchange, water relation, and biochemical parameters were recorded in similar ways as explained above.
2.4. Gas Exchange Parameters. Gas exchange parameters such as photosynthetic rate and transpiration rate were measured using an infrared gas analyser (Licor Biosciences, Lincoln, NE, USA) in the leaves before they were sampled for estimation of various biochemical constituents. The readings were measured in full sunlight between 10:00 and 12:00 noon. Photosynthetic rate was expressed as $\mu \mathrm{mol}$ $\mathrm{CO}_{2} \mathrm{~m}^{-1} \mathrm{sec}^{-1}$ while the transpiration rate was expressed as $\mathrm{mmol} \mathrm{H}_{2} \mathrm{O} \mathrm{m}^{-2} \mathrm{sec}^{-1}$. Water use efficiency at the level of a single leaf was derived using the formula WUE = photosynthetic rate/transpiration rate [7].

2.5. Water Relation Parameters. Relative water content (RWC) was estimated as per the procedures developed by Barrs and Weatherly [8]. To determine water and osmotic potential, leaf samples were collected on the day of observation, wrapped in aluminum foil, and brought to the laboratory in ice box. The leaf samples were stored immediately in a freezer. At the time of estimation, leaf samples were removed from the freezer and thawed at room temperature and the sap was extracted by gently spinning the leaf tissues. The leaf water potential was measured using water potential system model PSYPRO 8 channel connected to C $52-8 \mathrm{~F}$ sample chamber (Wescor Inc, Utah, USA) while osmotic potential was measured using vapour pressure osmometer (model 5600, Wescor Inc, Utah, USA).

2.6. Estimation of Biochemical Constituents. The total polyphenol content of the leaf extract was determined using the Folin-Ciocalteu method [9], using Gallic acid as the standard. The concentration of the total phenolics was expressed as the gallic acid equivalent (GAE $\mathrm{mg} \mathrm{g}^{-1}$ ) of the lyophilised sample. Reducing sugar was estimated by the dinitrosalicylic acid (DNSA) method, proline was estimated by the sulphosalicylic acid method, and total proteins were estimated using Lowry's method [10] using bovine serum albumin as a standard.

2.7. Statistical Analysis. Data were analyzed using SAS statistical software (version 9.2; SAS Institute, Cary, NC). The least significant difference was used to separate means between different treatments.

\section{Results}

3.1. Influence of Moisture Stress on Water Relation, Gas Exchange, and Biochemical Parameters. No significant differences in the photosynthetic rate and transpiration rate were observed during earlier stages of water stress cycle, while with the progress in stress cycle, there was variation in gas exchange parameters in all the rootstocks (Table 1). Higher transpiration rate in 1613C, Teleki 5A, Vitis longii, and St. George shows that the internal mechanism in these species is not well adapted to cope with moisture stress conditions. But rootstocks $110 \mathrm{R}$ and Dogridge recorded lower transpiration rate at moisture stress which may be attributed to increased availability of water in leaves through maintenance of cell turgidity. Water use efficiency was highest in $110 \mathrm{R}$ rootstock at the end of the stress cycle followed by $1103 \mathrm{P}$, 
TABLE 1: Gas exchange parameters, water relations, and biochemical parameters in grape rootstocks without stress before imposition of moisture stress.

\begin{tabular}{|c|c|c|c|c|c|c|c|c|c|}
\hline Rootstocks & $\begin{array}{c}\text { Transpiration } \\
\text { rate }(\mathrm{mmole} \\
\left.\mathrm{H}_{2} \mathrm{O} \mathrm{cm}^{-2} \mathrm{sec}^{-1}\right)\end{array}$ & $\begin{array}{l}\text { Photosynthetic rate } \\
\left(\mu \text { mole } \mathrm{cm}^{-2} \sec ^{-1}\right)\end{array}$ & $\begin{array}{c}\text { WUE } \\
(\mathrm{mmole} / \mu \text { mole })\end{array}$ & $\begin{array}{c}\mathrm{OP} \\
(\mathrm{MPa})\end{array}$ & $\begin{array}{l}\text { RWC } \\
(\%)\end{array}$ & $\begin{array}{l}\text { Phenols } \\
\left(\mathrm{mgg} \mathrm{g}^{-1}\right)\end{array}$ & $\begin{array}{l}\text { Proteins } \\
\left(\mathrm{mgg}^{-1}\right)\end{array}$ & $\begin{array}{l}\text { Proline } \\
\left(\mathrm{mgg}^{-1}\right)\end{array}$ & $\begin{array}{l}\text { Red sugars } \\
\left(\mathrm{mg} \mathrm{g}^{-1}\right)\end{array}$ \\
\hline $1103 \mathrm{P}$ & 1.09 & 39.13 & 36.03 & 1.57 & 92.91 & 14.09 & 259.91 & 0.134 & 197.37 \\
\hline $110 \mathrm{R}$ & 1.58 & 41.26 & 29.04 & 2.24 & 93.45 & 5.84 & 103.70 & 0.084 & 274.65 \\
\hline $1613 \mathrm{C}$ & 2.68 & 40.03 & 16.14 & 1.67 & 94.28 & 5.86 & 123.82 & 0.091 & 122.70 \\
\hline $99 \mathrm{R}$ & 1.92 & 41.83 & 23.73 & 1.56 & 93.89 & 15.13 & 290.37 & 0.083 & 127.07 \\
\hline B2-56 & 0.95 & 39.53 & 41.27 & 1.62 & 92.44 & 7.86 & 153.52 & 0.164 & 210.97 \\
\hline Dogridge & 1.80 & 40.60 & 23.64 & 1.74 & 94.61 & 6.43 & 134.15 & 0.217 & 152.65 \\
\hline Salt Creek & 1.06 & 39.26 & 37.58 & 1.56 & 92.80 & 14.50 & 264.48 & 0.138 & 203.24 \\
\hline St. George & 1.57 & 43.46 & 29.18 & 1.61 & 94.23 & 11.60 & 223.77 & 0.136 & 97.01 \\
\hline Teleki 5A & 1.66 & 40.60 & 31.82 & 1.49 & 92.80 & 9.00 & 153.64 & 0.091 & 132.07 \\
\hline V. longii & 1.24 & 39.20 & 31.89 & 1.50 & 93.81 & 5.34 & 111.71 & 0.181 & 197.58 \\
\hline SEM \pm & 0.370 & 0.8628 & 4.403 & 0.053 & 0.837 & 0.330 & 5.443 & 0.0141 & 5.524 \\
\hline $\begin{array}{l}\text { Level of } \\
\text { significance* }\end{array}$ & 0.1029 & 0.0361 & 0.0237 & $<0.001$ & 0.621 & $<0.0001$ & $<0.0001$ & $<0.0001$ & $<0.0001$ \\
\hline
\end{tabular}

${ }^{*}$ Values below 0.05 indicate significance at $P<0.05$.

TABLE 2: Gas exchange and water relation parameters of grape rootstocks of different stages of $50 \%$ moisture stress cycle.

\begin{tabular}{lccccccccccccccc}
\hline \multirow{2}{*}{ Rootstocks } & \multicolumn{9}{c}{ 7th day } & \multicolumn{1}{c}{ 14th day } & \multicolumn{4}{c}{ 21st day } \\
& $E$ & $A$ & WUE & OP & RWC & $E$ & $A$ & WUE & OP & RWC & $E$ & $A$ & WUE & OP & RWC \\
\hline 1103P & 0.92 & 38.76 & 62.92 & 2.99 & 81.33 & 1.28 & 42.16 & 33.10 & 4.26 & 78.26 & 3.37 & 34.66 & 10.58 & 2.03 & 73.00 \\
110R & 0.51 & 44.06 & 106.29 & 1.55 & 87.65 & 1.16 & 47.13 & 44.13 & 1.78 & 80.80 & 2.50 & 34.88 & 14.18 & 1.70 & 74.64 \\
1613C & 2.94 & 40.50 & 16.06 & 1.74 & 66.01 & 3.67 & 43.36 & 12.22 & 1.71 & 60.06 & 5.18 & 13.33 & 2.66 & 1.60 & 50.81 \\
99R & 0.88 & 40.60 & 55.96 & 2.43 & 81.45 & 1.77 & 43.23 & 24.85 & 2.43 & 80.11 & 3.54 & 30.94 & 8.86 & 1.66 & 72.80 \\
B2-56 & 2.84 & 40.63 & 50.26 & 2.14 & 82.19 & 1.32 & 43.80 & 36.03 & 1.95 & 78.31 & 3.14 & 31.12 & 10.61 & 1.98 & 68.97 \\
Dogridge & 0.88 & 37.40 & 54.99 & 2.22 & 82.78 & 1.89 & 43.40 & 25.60 & 2.50 & 77.81 & 2.59 & 26.10 & 10.31 & 2.79 & 66.33 \\
Salt Creek & 2.81 & 42.63 & 17.99 & 1.36 & 79.73 & 2.24 & 48.33 & 21.97 & 1.54 & 73.61 & 3.68 & 19.03 & 5.41 & 1.62 & 66.33 \\
St. George & 2.36 & 42.26 & 23.44 & 1.36 & 71.25 & 3.62 & 47.03 & 13.97 & 1.25 & 58.83 & 4.02 & 12.24 & 3.02 & 1.57 & 49.34 \\
Teleki 5A & 3.97 & 42.30 & 11.52 & 1.52 & 77.88 & 1.95 & 45.36 & 21.16 & 1.66 & 65.69 & 4.29 & 19.14 & 4.52 & 1.92 & 51.56 \\
V. longii & 3.03 & 39.03 & 12.94 & 2.47 & 74.76 & 3.84 & 43.90 & 11.44 & 1.91 & 70.14 & 4.71 & 18.53 & 3.93 & 20.7 & 52.35 \\
\hline SEM \pm & 0.866 & 1.284 & 18.972 & 0.116 & 2.044 & 0.320 & 1.025 & 4.256 & 0.1624 & 1.860 & 0.410 & 1.812 & 0.735 & 0.237 & 1.789 \\
\hline
\end{tabular}

Level of $*_{*} 0.104 \quad 0.040 \quad 0.0369<0.0001<0.0001<0.00010 .0040 .0003<0.0001<0.00010 .002<0.0001<0.0001<0.0001<0.0001$ significance

${ }^{*}$ Values below 0.05 indicate significance at $P<0.05$. E: transpiration rate; $A$ : photosynthetic rate; WUE: water use efficiency; OP: osmotic potential; RWC: relative water content.

B2-56, and Dogridge at 50\% moisture stress (Table 2). There was reduction in water use efficiency in all the rootstock with the progress of stress cycle. Rootstocks such as Teleki 5A, St. George, 1613C, and Vitis longii did not exhibit any photosynthetic rate on the 21st day of the stress cycle as the leaves must have reached wilting point by that time.

Among water relation parameters, relative water content decreased in all the rootstocks at 50\% moisture stress with the progress in the stress cycle. At the end of the stress cycle, maximum RWC was recorded on 110R, 1103P, and 99R rootstock, while it was the least on St. George, 1613C, and Vitis longii. Data on osmotic potential indicate the osmotic adjustment in response to moisture stress by accumulation of compatible solutes in the cells to maintain cell turgidity of the cell. Maximum osmotic potential was recorded on $1103 \mathrm{P}$ followed by those on Salt Creek, 110R, and 99R. The least osmotic potential was recorded on Dogridge rootstocks.

Phenolic accumulation was highest on 110R and B2/56 rootstocks at the end of stress cycle at $50 \%$ moisture stress. There was reduction in the protein content with the advance of stress cycle in all the rootstocks. However, among rootstocks the protein accumulation was highest in 110R, 1103P, and $\mathrm{B} 2 / 56$ at the end of stress cycle while it was the least on 1613C rootstock. Significant difference in accumulation of proline was recorded in different rootstocks at different stages of stress cycle. The unstressed vines recorded very less concentration, while with the progress in stress cycle there was significant increase in accumulation of proline. Highest 
TABLE 3: Biochemical composition of grape rootstocks at different stages of 50\% moisture stress cycle.

\begin{tabular}{|c|c|c|c|c|c|c|c|c|c|c|c|c|}
\hline \multirow[b]{2}{*}{ Rootstocks } & \multicolumn{4}{|c|}{ 7th day } & \multicolumn{4}{|c|}{ 14th day } & \multicolumn{4}{|c|}{ 21st day } \\
\hline & $\begin{array}{l}\text { Phenols } \\
\left(\mathrm{mg} \mathrm{g}^{-1}\right)\end{array}$ & $\begin{array}{l}\text { Proteins } \\
\left(\mathrm{mg} \mathrm{g}^{-1}\right)\end{array}$ & $\begin{array}{l}\text { Proline } \\
\left(\mathrm{mgg}^{-1}\right)\end{array}$ & $\begin{array}{c}\text { Red } \\
\text { sugar } \\
\left(\mathrm{mgg}^{-1}\right)\end{array}$ & $\begin{array}{l}\text { Phenols } \\
\left(\mathrm{mg} \mathrm{g}^{-1}\right)\end{array}$ & $\begin{array}{l}\text { Proteins } \\
\left(\mathrm{mg} \mathrm{g}^{-1}\right)\end{array}$ & $\begin{array}{l}\text { Proline } \\
\left(\mathrm{mgg}^{-1}\right)\end{array}$ & $\begin{array}{c}\text { Red } \\
\text { sugar } \\
\left(\mathrm{mgg}^{-1}\right)\end{array}$ & $\begin{array}{l}\text { Phenols } \\
\left(\mathrm{mg} \mathrm{g}^{-1}\right)\end{array}$ & $\begin{array}{l}\text { Proteins } \\
\left(\mathrm{mgg}^{-1}\right)\end{array}$ & $\begin{array}{l}\text { Proline } \\
\left(\mathrm{mgg}^{-1}\right)\end{array}$ & $\begin{array}{c}\text { Red sugars } \\
\left(\mathrm{mg} \mathrm{g}^{-1}\right)\end{array}$ \\
\hline $1103 \mathrm{P}$ & 14.57 & 167.94 & 0.98 & 238.43 & 10.96 & 185.30 & 11.75 & 120.08 & 7.87 & 117.26 & 12.63 & 302.14 \\
\hline $110 \mathrm{R}$ & 8.41 & 80.60 & 2.92 & 160.77 & 11.72 & 186.30 & 15.76 & 160.08 & 12.18 & 192.11 & 16.01 & 329.35 \\
\hline $1613 C$ & 7.15 & 89.36 & 0.87 & 189.72 & 7.16 & 115.39 & 7.96 & 153.94 & 3.12 & 27.19 & 6.22 & 299.83 \\
\hline $99 \mathrm{R}$ & 13.62 & 186.21 & 1.22 & 213.09 & 12.99 & 241.34 & 13.61 & 204.78 & 7.04 & 90.86 & 11.16 & 333.91 \\
\hline B2-56 & 14.83 & 170.92 & 1.53 & 236.28 & 17.71 & 189.71 & 14.80 & 232.07 & 11.45 & 104.68 & 11.45 & 356.43 \\
\hline Dogridge & 12.68 & 172.82 & 1.41 & 224.51 & 10.85 & 100.99 & 13.69 & 145.43 & 6.03 & 70.80 & 11.17 & 389.44 \\
\hline Salt Creek & 10.04 & 127.48 & 0.88 & 223.63 & 9.00 & 139.49 & 15.88 & 147.86 & 5.35 & 36.23 & 10.93 & 293.73 \\
\hline St. George & 12.27 & 122.77 & 0.33 & 208.87 & 11.08 & 157.71 & 10.78 & 100.78 & 2.88 & 53.04 & 7.22 & 264.30 \\
\hline Teleki 5A & 13.44 & 144.42 & 0.69 & 266.35 & 13.28 & 193.56 & 9.86 & 168.35 & 5.92 & 64.83 & 8.23 & 211.60 \\
\hline$V$. longii & 12.65 & 135.84 & 1.29 & 248.63 & 12.37 & 200.85 & 9.08 & 174.58 & 6.83 & 76.13 & 6.50 & 431.42 \\
\hline $\mathrm{SEM} \pm$ & 0.614 & 6.089 & 0.221 & 11.129 & 0.475 & 30.704 & 1.225 & 17.815 & 0.485 & & & \\
\hline $\begin{array}{l}\text { Level of } \\
\text { significance* }^{*}\end{array}$ & $<0.0001$ & $<0.0001$ & $<0.0001$ & $<0.0001$ & $<0.0001$ & 0.108 & 0.0009 & 0.0023 & $<0.0001$ & $<0.0001$ & $<0.0001$ & $<0.0001$ \\
\hline
\end{tabular}

${ }^{*}$ Values below 0.05 indicate significance at $P<0.05$.

proline content was recorded in 110R followed by those on 1103P, 99R, B2-56, and Dogridge rootstock, while it was the least on 1613C and Vitis longii (Table 3).

3.2. Influence of Salinity Stress on Water Relation and Biochemical Parameters. In both salinity levels, there was increase in osmotic potential with the progress in stress cycle with corresponding decrease in water potential (Table 4). Significant difference was recorded for osmotic potential between two levels of salinity with lowest osmotic potential in $2 \mathrm{dS} \mathrm{m}^{-1}$ on the 5th day while it was highest on the 15th and 25th day. Though there was variation in osmotic potential between two levels of salinity, the values were not significantly different in biochemical constituents such as proteins and phenolic compounds in the beginning of stress cycle. With the progress in stress cycle, there was rapid accumulation of reducing sugars and proteins at $4 \mathrm{dS} \mathrm{m}^{-1}$ level at the end of stress cycle, while highest phenol was recorded at $2 \mathrm{dS} \mathrm{m}^{-1}$ salinity level. At the end of the stress cycle, highest osmotic adjustment in terms of increased osmotic potential was recorded at $2 \mathrm{dS} \mathrm{m}^{-1}$ level rather than at $4 \mathrm{dS} \mathrm{m}^{-1}$.

Significant differences in water relations and biochemical constituents were recorded among rootstock with the progress of stress cycle. There was increase in osmotic potential in most of the rootstocks with the corresponding decrease in water potential with progress of stress cycle. Highest osmotic potential was recorded in $110 \mathrm{R}, 1103 \mathrm{P}, \mathrm{B} 2-$ $56,99 \mathrm{R}$, and Dogridge in the beginning of salinity stress cycle which maintained the same trend till the end of the stress cycle. The increased osmotic potential was associated with corresponding increase in accumulation of organic compounds such as reducing sugars, proteins, and phenolic compounds in the same rootstock.

Significant differences were recorded among rootstocks in accumulation of reducing sugar, total phenol, and protein content at both 2 and $4 \mathrm{dS} \mathrm{m}^{-1}$ levels at the end of the stress cycle. At $2 \mathrm{dS} \mathrm{m}^{-1}$ level, most of the resistant rootstocks such as $110 \mathrm{R}$, Dogridge, Salt Creek, and B2/56 have maximum reducing sugar, while at $4 \mathrm{dS} \mathrm{m}^{-1}$ level, most of the susceptible rootstocks accumulated maximum reducing sugars at later stages of the stress cycle. Protein accumulation increased with increase in salinity stress and this may be due to accumulation of stress responsive proteins. Salt Creek, B2/56, 110R, and Dogridge recorded highest protein accumulation at $4 \mathrm{dS} \mathrm{m}^{-1}$ level while the least was in 1613C, Vitis longii, Teleki 5A, and 99R. Accumulation of phenolic compounds was highest in most of the rootstocks at $2 \mathrm{dS} \mathrm{m}^{-1}$ level, while at $4 \mathrm{dS} \mathrm{m}^{-1}$ level, there was slight decrease in phenolic content even in the resistant rootstocks such as Salt Creek, B2/56, and 110R.

Significant interaction effect of salt stress and rootstocks was recorded on the 15 th and 25 th day of stress cycle with respect to accumulation of most of the organic compounds.

\section{Discussion}

4.1. Water Relation and Gas Exchange Parameters in response to Moisture and Salinity Stresses. Relative water content, leaf water potential, and leaf osmotic potential in the beginning of the stress cycle were similar in all the rootstocks suggesting the similar behaviour of all the rootstocks. Their ability to cope with induced moisture stress is evident under $50 \%$ stress. The maintenance of high RWC in 110R, 1103P, B2/56, and Dogridge indicates their ability to maintain turgidity even under soil moisture stress conditions. This is evident from high water potential in 110R, 99R, and B2/56 under high salinity conditions at the end of the stress cycle. The lowering of leaf osmotic potential indicates the osmotic adjustment and it varies from rootstock to rootstock. The osmotic potential of rootstocks exposed to $2 \mathrm{dS} \mathrm{m}^{-1}$ salinity levels was higher than that at $4 \mathrm{dS} \mathrm{m}^{-1}$ level indicating nontolerance of 


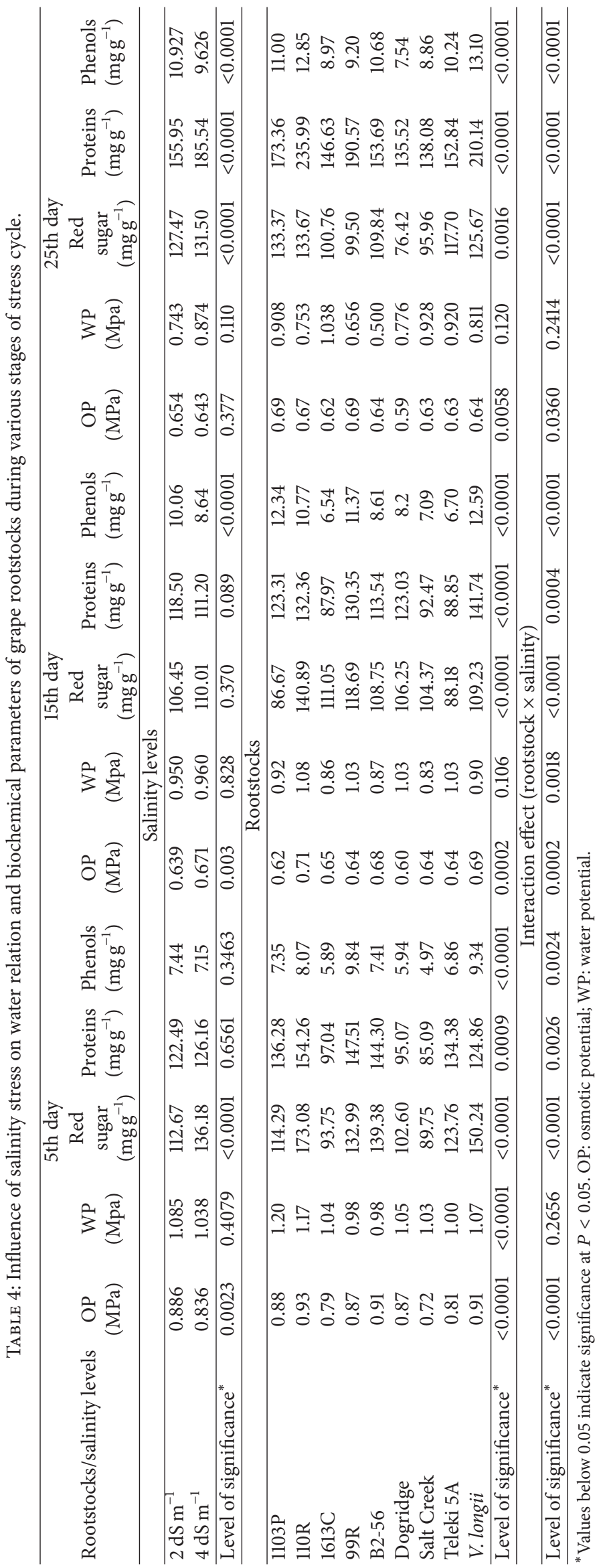


most of the rootstocks to higher salinity levels efficiently. During and Dry [11] reported that lowering of osmotic potential in response to soil moisture stress may help in maintaining required water relation parameters. Schultz [12] also obtained striking differences in the relationship between osmotic potential, turgor potential, water potential, and RWC of grape leaves, which he related to the differences in the apoplastic water content. The rootstocks such as 110R, 1103P, Dogridge, and B2/56 maintained better osmotic adjustment at 50\% moisture stress and at $2 \mathrm{dS} \mathrm{m}^{-1}$ salinity stress at the end of the stress cycle as indicated by leaf water potential. The increased osmotic adjustment in these rootstocks has been attributed to increased sugar and other compatible solutes [13]. Similarly water stress reduced both water and turgor potential in grape vines but stressed plants tried to maintain turgor potential by osmotic adjustment. The reduction in leaf water potential induces stomatal closure and increases abscisic acid levels in leaves [14]. In studies on contribution of various mechanisms involved in diurnal changes of osmotic potential in leaves of grape cultivar Victoria under stressed condition, dehydration accounts for $36 \%$ of the diurnal changes in osmotic potential in stressed plants. Net accumulation of solutes accounted for $73 \%$ of the diurnal changes indicating the occurrence of an active osmotic adjustment during the day in stressed plants [15]. The present investigation also reveals the increased osmotic adjustment in the above-mentioned 4 rootstocks at both moisture and salinity stresses due to accumulation of organic solutes. Zhongqun et al. [16] in their studies on the osmotic adjustment in tomato subjected to sodium chloride stresses recorded higher accumulation of soluble sugars, proteins, and proline under salinity resulting in greater osmotic adjustment in saline conditions. Some of the rootstocks in the present study such as 1613C, St. George, and Vitis longii showed wilting symptom at $50 \%$ moisture stress at the end of the stress cycle which may be attributed to their reduced RWC in leaves due to less accumulation of osmolytes resulting in loss of turgidity in cells.

The marginal reduction in photosynthesis and greater reduction in transpiration rate under moisture stress may be due to reduced stomatal conductance in most of the rootstocks which is similar to findings of Reynolds and Naylor [17], where transpiration rate and stomatal conductance reduced progressively with increase in duration of water stress in grapevines. Lakso [18] also reported the marginal reduction in photosynthesis and greater reduction in transpiration rate in grape vines under moisture stress conditions. The marginal reduction in photosynthesis and greater reduction in transpiration rate in rootstocks $110 \mathrm{R}, 1103 \mathrm{P}$, B2/56, 99R, and Dogridge must have resulted in increased WUE. Similar increase in WUE at decreased water potential was reported by Behboudian et al. [19] in pistachio varieties.

Vines that are mildly water stressed tend to be more water-use efficient than unstressed vines because transpiration is reduced more than photosynthesis [20]. This might explain the maintenance of high water use efficiency in rootstocks such as 110R, 1103P, 99R, and B2/56 and to some extent in Dogridge. The reduced WUE in susceptible cultivars such as 1613C, St. George, and Vitis longii must have resulted in reduced accumulation of biomass thus showing wilting symptoms at the end of the stress cycle. Biomass reduction caused by salinity and drought is associated with equivalent reduction in transpiration [21].

4.2. Biochemical Parameters in response to Moisture and Salinity Stresses. Under salt stress conditions higher plants accumulate several organic osmolytes and inorganic ions (mostly $\mathrm{K}$ and $\mathrm{Ca}$ ) to make higher osmotic adjustment and to maintain a favourable gradient for water flow from soil to roots [22]. This increased accumulation of organic and inorganic compounds in response to abiotic stresses might have resulted in improved stress tolerance [23]. Some of the osmoprotectants which commonly accumulate in crop plants are sugars, amino acids (proline), and quaternary ammonium compounds (glycine betaine).

Other compounds which are known as stress indicators in several plant species are phenolic compounds. Leaf phenolic contents are important protective components of plant cells. The potential of phenolics to act as an antioxidant is mainly due to their properties to act as hydrogen donators, reducing agents and quenchers of singlet $\mathrm{O}^{-2}$ [24]. The synthesis of phenolic compounds is affected either positively or negatively in response to abiotic or biotic stresses [25]. We could observe variation among rootstocks in accumulation of several biochemical compounds in response to both moisture and salinity stresses. Accumulation of phenolic compounds was highest in $110 \mathrm{R}$ rootstock at the end of the stress cycle which increased with the progress of stress cycle. But, in rootstocks 1103P, B2/56, and 99R there was slight reduction in phenolic contents in the order next to that of 110R. Rootstocks 1613C and St. George recorded minimum content of phenols towards the end of the stress cycle.

The present investigation with respect to accumulation of phenols in drought tolerant grape rootstocks is similar to the findings of Dostanova et al. [26] and Latha et al. [27], where in the tolerant genotypes showed a higher level of total phenols and significant reduction was observed in susceptible genotypes. Thus, phenol accumulation in tolerant genotypes could be a cellular adaptive mechanism for scavenging the free radicals of oxygen and preventing subcellular damage during stress.

The drastic increase in the content of proline was observed in most of the rootstocks though the concentration varied among them. Rootstocks 1103P, 110R, 99R, B2/56, Dogridge, and Salt Creek recorded highest concentration of proline at the end of the stress cycle while the least was in 1613C and Vitis longii. Proline in addition to its role as an osmolyte and a reservoir of carbon and nitrogen has been shown to protect plants against free radical induced damage [28].

Some of the other biochemical compounds which are known to accumulate in response to these stresses are proteins. Accumulation of several types of proteins is also one of the strategies by which plants adapt to abiotic stress conditions such as drought and salinity. Though there was reduction in protein content in most of the rootstocks with progress in moisture stress cycle, some of the rootstocks 
such as 110R, 1103P, and B2/56 accumulated considerably higher concentration of proteins, which also recorded highest RWC and water potential indicating their tolerance to moisture stress. Similarly under high saline conditions of $4 \mathrm{EC}$ there was increased accumulation of proteins in some rootstocks such as Salt Creek, B2-/56, 110R, and Dogridge. Similar findings were reported in other crop plants regarding accumulation of proteins under conditions of abiotic stresses. In sugar cane a specific protein of $18 \mathrm{kDa}$ was found in leaves of drought tolerant cultivars which were not identified in sensitive cultivars [29]. Similarly in Barley, increased salinity concentration increased the protein concentration from 2.5 to 3.0 folds than in control. The elevated protein content was attributed to the results of a general increase in most polypeptides and a pronounced increase in the abundance of specific polypeptides of apparent molecular markers.

The accumulation of reducing sugar exhibited a different trend wherein there was slight reduction in reducing sugar in most of the rootstocks at the middle of moisture stress cycle which increased later with the progress of the cycle. There was increased accumulation of sugars in rootstock Vitis longii which showed reduced RWC during that period. Water soluble carbohydrates and fructans are the sensitive markers for the selection of tolerant genotypes under salt stress [30]. Salt tolerant genotypes of wheat accumulated more carbohydrates compared to sensitive genotypes. High carbohydrates concentration under salt stress prevents plants from oxidative damage and also maintains the structure of proteins [31]. The three-fold increase in sugar content in Vitis longii at the end of moisture stress cycle under stress conditions in spite of its lower RWC and less turgidity indicates that higher accumulation of sugars than a particular concentration is injurious to plants resulting in morphological deformities such as stunted growth and chlorotic and necrotic leaves. Similarly under salinity stress conditions some of the susceptible rootstocks exhibited increased accumulation of reducing sugar at $4 \mathrm{dS} \mathrm{m}^{-1}$ level than that of resistant cultivars.

\section{Conclusion}

Two separate experiments were conducted to evaluate the response of grape rootstocks to imposed moisture stress and salinity conditions. It is clearly shown that rootstocks exhibited significant variation among gas exchange parameters and water relation parameters. Rootstocks belonging to Vitis berlandieri $\times$ Vitis rupestris (110R, 1103P, 99R, and B2/56) showed better osmotic adjustment and increased water use efficiency followed by the rootstocks belonging to Vitis champinii species (Dogridge and Salt Creek). Accumulation of high phenols in resistant rootstocks can be one of the indicators for screening rootstocks for abiotic stresses studied. From both studies it is clear that rootstocks belonging to Vitis berlandieri $\times$ Vitis rupestris have better tolerance mechanisms to salinity and moisture stress. Further, studies are needed to evaluate performance of those rootstocks to combined effect of moisture stress and soil salinity. In-depth study with respect to influence of rootstocks on grafted scions under conditions of salinity and moisture stress will help to recommend better salt and drought tolerant rootstocks for semiarid tropical grape growing regions of India.

\section{Conflict of Interests}

The authors declare that there is no conflict of interests regarding the publication of this paper.

\section{Acknowledgments}

The authors are grateful for the funding provided by Board of Research for Nuclear Studies, Bhabha Atomic Research Centre, Mumbai, India, to carry out this study under the Project "Identification of Drought and Salt Stress Tolerance Genes in Grape Rootstocks under the Conditions of Abiotic Stresses."

\section{References}

[1] J. Satisha, G. S. Prakash, R. M. Bhatt, and P. Sampath Kumar, "Physiological mechanisms of water use efficiency in grape rootstocks under drought conditions," International Journal of Agricultural Research, vol. 2, no. 2, pp. 159-164, 2007.

[2] M. C. Candolfi-Vasconcelos, W. Koblet, G. S. Howell, and W. Zweifel, "Influence of defoliation, rootstock, training system, and leaf position on gas exchange of Pinot noir grapevines," American Journal of Enology and Viticulture, vol. 45, no. 2, pp. 173-180, 1994.

[3] L. E. Williams and R. J. Smith, "The effect of rootstocks on the partitioning of dry weight, nitrogen, potassium and root distribution of Cabernet Sauvignon grapevine," American Journal of Enology and Viticulture, vol. 42, pp. 118-122, 1991.

[4] M. Ashraf and P. J. C. Harris, "Potential biochemical indicators of salinity tolerance in plants," Plant Science, vol. 166, no. 1, pp. 3-16, 2004.

[5] M. M. Posmyk, R. Kontek, and K. M. Janas, "Antioxidant enzymes activity and phenolic compounds content in red cabbage seedlings exposed to copper stress," Ecotoxicology and Environmental Safety, vol. 72, no. 2, pp. 596-602, 2009.

[6] Y. Wang and N. Nii, "Changes in chlorophyll, ribulose bisphosphate carboxylase-oxygenase, glycine betaine content, photosynthesis and transpiration in Amaranthus tricolor leaves during salt stress," Journal of Horticultural Science and Biotechnology, vol. 75, no. 6, pp. 623-627, 2000.

[7] J. Bota, J. Flexas, and H. Medrano, "Genetic variability of photosynthesis and water use in Balearic grapevine cultivars," Annals of Applied Biology, vol. 138, no. 3, pp. 353-361, 2001.

[8] H. D. Barrs and P. E. Weatherly, "A re-examination of the relative turgidity techniques for estimating water deficits in leaves," Australian Journal of Biological Sciences, vol. 15, pp. 413-428, 1962.

[9] V. L. Singleton and J. A. Rossi, "Colorimetry of total phenolic with phosphomolybdic phosphotungstic acid reagents," American Journal of Enology and Viticulture, vol. 16, pp. 144-158, 1965.

[10] J. M. Dawson and P. L. Heatlie, "Lowry method of protein quantification: evidence for photosensitivity," Analytical Biochemistry, vol. 140, no. 2, pp. 391-393, 1984.

[11] H. During and P. R. Dry, "Osmoregulation in water stressed roots: responses of leaf conductance and photosynthesis," Vitis, vol. 34, no. 1, pp. 15-17, 1995. 
[12] H. R. Schultz, "Physiological mechanisms of water use efficiency in grapevines under drought conditions," Acta Horticulturae, vol. 526, pp. 115-136, 2000.

[13] M. L. Rodrigues, M. M. Chaves, M. Wendler et al., "Osmotic adjustment in water stressed grapevines in relation to carbon assimilation," Australian Journal of Plant Physiology, vol. 20, pp. 309-321, 1993.

[14] S. Nagarajah, "Physiological response of grape vines to water stress," Acta Horticulturae, vol. 240, pp. 249-256, 1989.

[15] A. Patakas and B. Noitsakis, "Mechanisms involved in diurnal changes of osmotic potential in grapevines under drought conditions," Journal of Plant Physiology, vol. 154, no. 5-6, pp. 767-774, 1999.

[16] H. Zhongqun, T. Haoru, L. Huanxium, H. Chaoxing, Z. Zhibin, and W. Hauisang, "Arbuscualr Mycorrhizal alleviated ion toxicity, oxidative damage and enhanced osmotic adjustment in tomato subjected to $\mathrm{NaCl}$ stress," American, vol. 7, pp. 676-683, 2010.

[17] A. G. Reynolds and A. P. Naylor, "Pinot noir' and 'Riesling' grapevines respond to water stress duration and soil waterholding capacity," HortScience, vol. 29, no. 12, pp. 1505-1510, 1994.

[18] A. N. Lakso, "The effect of water stress on physiological processes in fruit crops," Acta Horticulturae, vol. 171, pp. 275-290, 1985.

[19] M. H. Behboudian, R. R. Walker, and E. Törökfalvy, "Effects of water stress and salinity on photosynthesis of pistachio," Scientia Horticulturae, vol. 29, no. 3, pp. 251-261, 1986.

[20] M. M. Chaves, T. P. Santos, C. R. Souza et al., "Deficit irrigation in grapevine improves water-use efficiency while controlling vigour and production quality," Annals of Applied Biology, vol. 150, no. 2, pp. 237-252, 2007.

[21] U. Shani and L. M. Dudley, "Field studies of crop response to water and salt stress," Soil Science Society of America Journal, vol. 65 , no. 5, pp. 1522-1528, 2001.

[22] J. M. Morgan, "Osmoregulation and water stress in higher plants," Annual Review of Plant Physiology, vol. 33, pp. 299-319, 1984.

[23] H. Greenway and R. Munns, "Mechanisms of salt tolerance in non-halophytes," Annual Review of Plant Physiology, vol. 31, pp. 149-190, 1980.

[24] C. A. Rice-Evans, N. J. Miller, and G. Paganga, "Antioxidant properties of phenolic compounds," Trends in Plant Science, vol. 2, no. 4, pp. 152-159, 1997.

[25] A. K. Parida, A. B. Das, Y. Sanada, and P. Mohanty, "Effects of salinity on biochemical components of the mangrove, Aegiceras corniculatum," Aquatic Botany, vol. 80, no. 2, pp. 77-87, 2004.

[26] R. Dostanova, L. K. Klysheve, and K. A. Toibaeva, "Phenol compounds of pea roots under salinization of the medium," Fiziologiya-i-Biokhimiya Kul'turnykh Rastenii, vol. 11, pp. 40-47, 1979.

[27] V. M. Latha, V. N. Satakopan, and H. Jayasree, "Salinity induced changes in phenol and ascorbic acid content in groundnut (Arachis hypogaea) leaves," Current Science, vol. 58, pp. 151-152, 1989.

[28] J. Matysik, A. Alia, B. Bhalu, and P. Mohanty, "Molecular mechanisms of quenching of reactive oxygen species by proline under stress in plants," Current Science, vol. 82, no. 5, pp. 525532, 2002.

[29] N. Jangpromma, S. Kitthaisong, S. Dadung, P. Jaisil, and S. Thammasirirak, " $18 \mathrm{KDa}$ protein accumulation in sugarcane leaves under drought stress conditions," KMITL Science Technology Journal, vol. 7, pp. 44-54, 2007.

[30] I. Kerepesi and G. Galiba, "Osmotic and salt stress-induced alteration in soluble carbohydrate content in wheat seedlings," Crop Science, vol. 40, no. 2, pp. 482-487, 2000.

[31] S. Hajihashemi, K. Kiarostami, S. Enteshari, and A. Saboora, "The effects of salt stress and paclobutrazol on some physiological parameters of two salt-tolerant and salt-sensitive cultivars of wheat," Pakistan Journal of Biological Sciences, vol. 9, no. 7, pp. 1370-1374, 2006. 


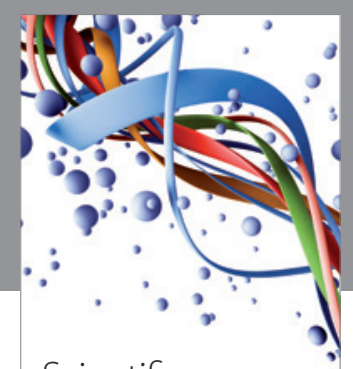

Scientifica
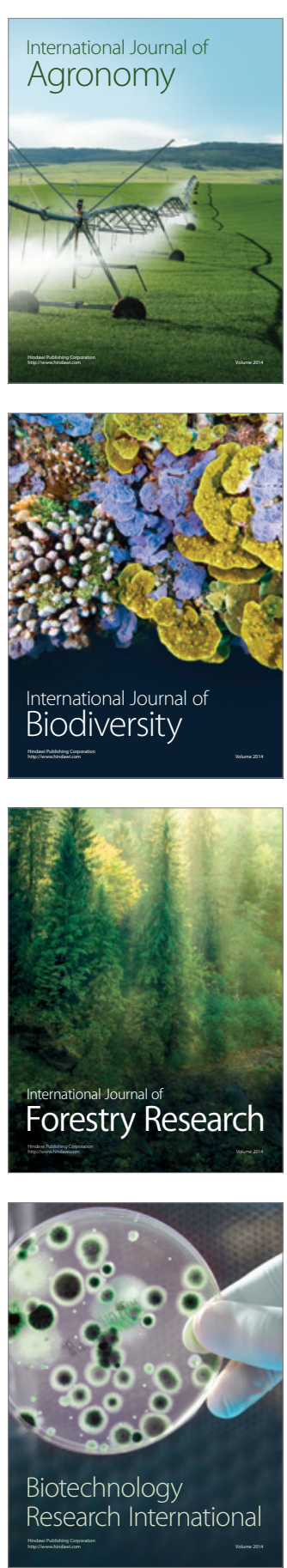
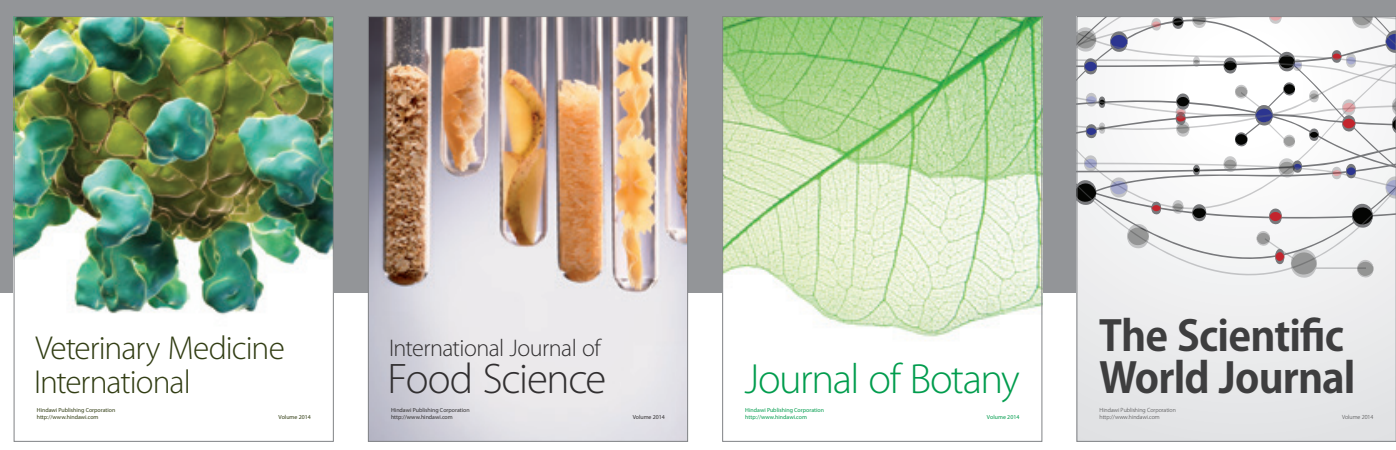

The Scientific World Journal
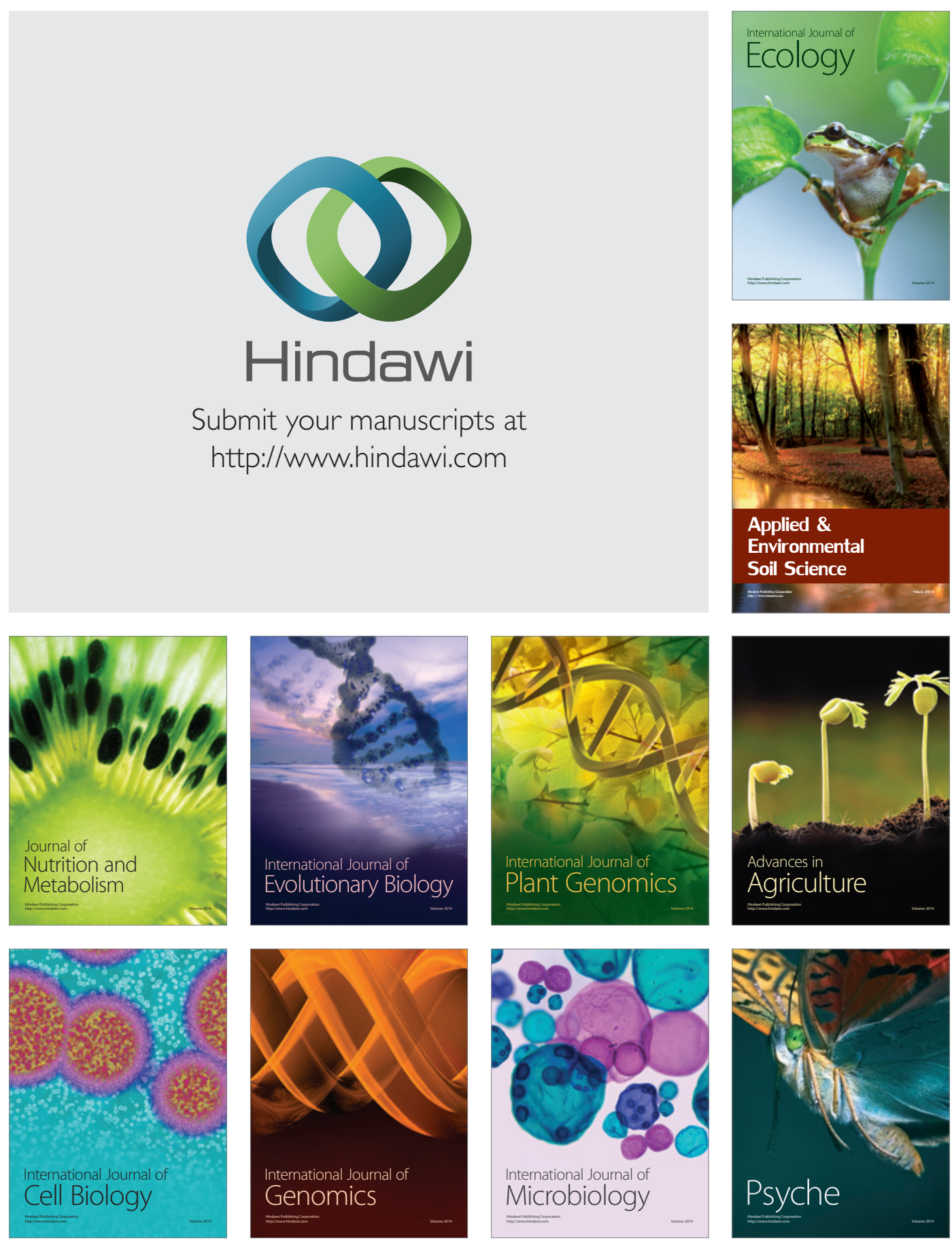